\title{
Functional Forces on Complete Dentures During Swallowing and Mastication
}

\author{
by \\ A. D. PAMIR and B. KALIPCILAR \\ (Received 11 January and accepted 15 January 1988)
}

Key words: functional forces, complete dentures, strain gauges

\begin{abstract}
In this study, the functional forces acting on maxillary complete dentures during mastication and swallowing were determined from three different locations by means of strain gauges. It was found that the functional forces caused by swallowing are quite marked in themselves and can cause deformation of the denture base resulting in undesirable force on the denture-bearing tissues.
\end{abstract}

\section{Introduction}

During the greater part of everyday life the jaws are in a rest position. Nevertheless, it is a fact that even in the rest position, various functional movements such as those for swallowing, smiling and speaking are performed and the resultant forces are transmitted to the supporting tissues through the denture bases ${ }^{[1]}$.

As certain degenerative and resorptive alterations occur in supportive tissues due to these functional forces, alterations to the form and properties of the denture base and its deformation can also be observed ${ }^{[2]}$.

From the dentist's viewpoint, the most important objective is not only that a prosthesis should resist any functional forces but that it should also maintain the health of the supporting tissues ${ }^{[1,3]}$. For this reason the material to be used as a denture base should be taken into consideration and undesirable functional forces should be avoided by the patient. In a review of the literature it was found that many attempts have been made to evaluate the functional forces which cause deformation to the base and their effects on the supporting tissues ${ }^{[2,4-10]}$.

A normal person performs just one reflex swallowing action per minute between meals and 9 per minute during meals ${ }^{[10,11]}$. It is observed that some people perform one and a half reflex swallowing actions per minute. If we consider that reflex swallowing continues even during sleep, though at a low rate, we can say that this reflex is repeated approximately $1100-1500$ times in 24 hours $^{[11,12]}$.

Undoubtedly, if there is an anomaly in the swallowing reflex, such a repeated action will produce even more pressure on the underlying tissues ${ }^{[11]}$, thus giving rise to the problem that such a swallowing force will affect the denture base along 
with the natural teeth and their anatomic structure. The next problem to consider is the type of deformation that will occur and the magnitude of the force.

In the present study we investigated the different swallowing functions plus the magnitude of forces that occur during chewing in vivo and in vitro by placing strain gauges in three different locations on maxillary complete dentures and determined the effects of these swallowing forces.

\section{Materials and Methods}

Four males and four females, eight patients in all, having a normal intermaxillary space and rather similar ridge surfaces, were chosen for our study.

Dentures were manufactured by the usual methods and three weeks were allowed for the patients to get used to them. Afterwards three strain gauges were placed in position as follows:

1) Under the contact area of the second molar and the first molar teeth unilaterally (G1).

2) Approximately $1 \mathrm{~cm}$ in front of the post-dam area (G2).

3) Behind the maxillary incisors on the median line (G3) (Figs. 1 and 2).

On the other side, "static loading models" were prepared from self-curing acrylic for use in static loading. Again, another denture bearing three strain gauges in similar positions to those in the test dentures was manufactured to serve as a "com-

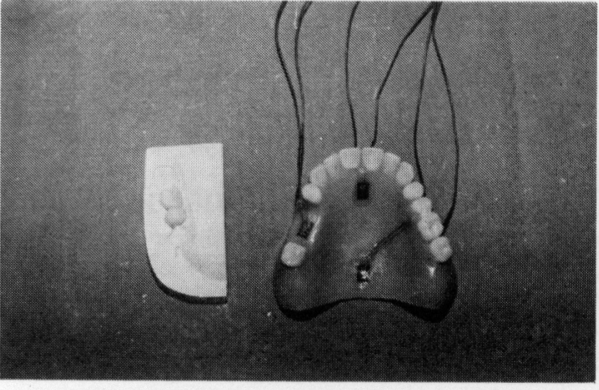

Fig. 1 Test dentures with strain gauges and their connections

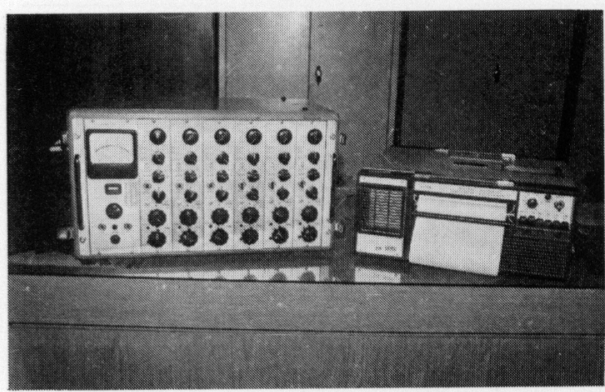

Fig. 3 Frequency amplifier and the optical recorder

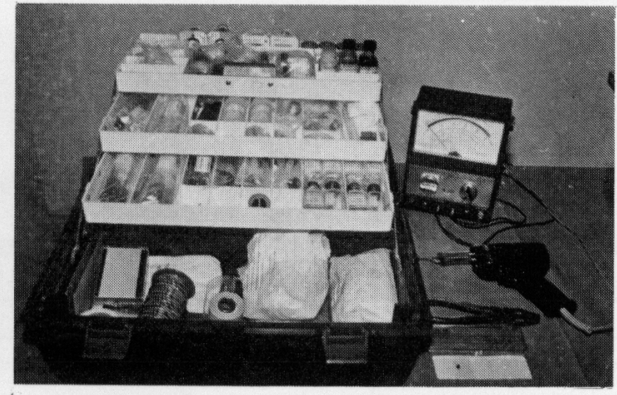

Fig. 2 Strain gauges, bonding agents and the indicator

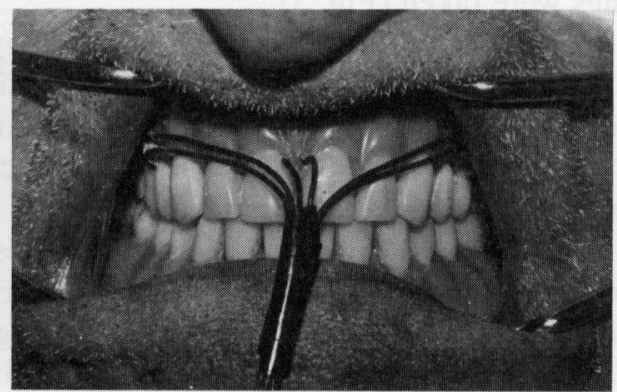

Fig. 4 Test dentures with strain gauges and their connections in the mouth 


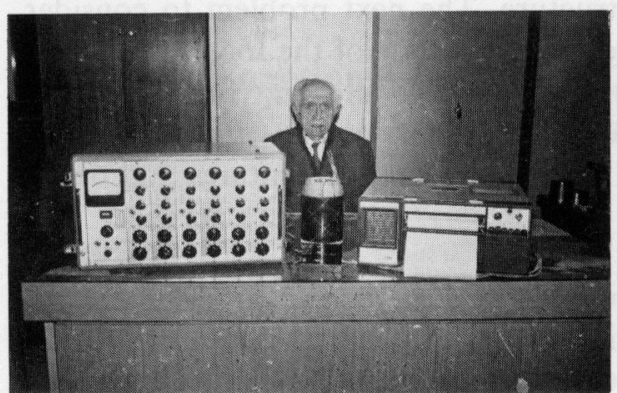

Fig. 5 Test denture and its connection to the system

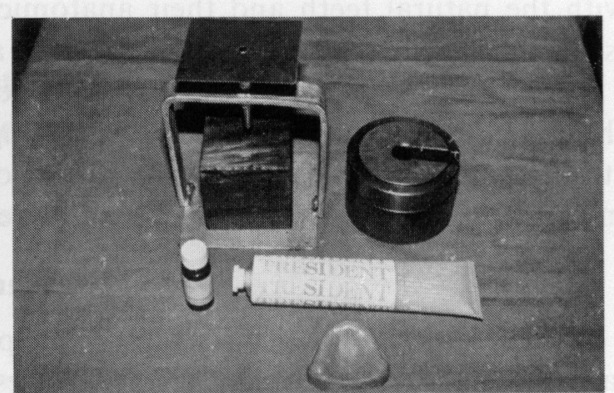

Fig. 6 The static loading model and the loading device which was used in in vitro recordings

Table 1 Average values of the forces in grams which were obtained for the different functions

\begin{tabular}{|c|c|c|c|c|c|c|c|c|c|c|c|c|c|}
\hline \multicolumn{2}{|c|}{ Patient } & \multicolumn{3}{|c|}{ Swallowing } & \multicolumn{3}{|c|}{ Drinking water } & \multicolumn{3}{|c|}{$\begin{array}{c}\text { Swallowing } \\
\text { after chewing }\end{array}$} & \multicolumn{3}{|c|}{ Mastication } \\
\hline Name & No. & G1 & $\mathrm{G} 2$ & G3 & G1 & $\mathrm{G} 2$ & G3 & G1 & $\mathrm{G} 2$ & G3 & G1 & $\mathrm{G} 2$ & G3 \\
\hline R.E. & 4170 & 3332 & 37 & 199 & 1839 & 15 & 13 & 2856 & 33 & 195 & 4280 & 5000 & 6660 \\
\hline M.B & 4363 & 2618 & 23 & 120 & 1666 & 23 & 19 & 3094 & 17 & 143 & 3570 & 3000 & 1330 \\
\hline S.Y. & 05366 & 1839 & 40 & 132 & 1602 & 27 & 17 & 1547 & 28 & 164 & 3920 & 5000 & 6660 \\
\hline M.I. & 08928 & 1661 & 23 & 109 & 1365 & 18 & 15 & 1424 & 33 & 136 & 3380 & 5000 & 6660 \\
\hline S.B. & 03044 & 1839 & 38 & 116 & 925 & 25 & 24 & 3332 & 70 & 141 & 7140 & 5000 & 3330 \\
\hline A.Ö. & 14182 & 5712 & 37 & 133 & 2380 & 22 & 15 & 4167 & 27 & 164 & 8930 & 5000 & 6670 \\
\hline B.T. & 05382 & 4284 & 78 & 284 & 3927 & 28 & 28 & 3332 & 40 & 224 & 3570 & 2000 & 4660 \\
\hline A.Y. & 11153 & 1789 & 50 & 138 & 1483 & 32 & 16 & 1602 & 32 & 155 & 3560 & 3000 & 2660 \\
\hline
\end{tabular}

pensating denture."

After connecting the whole system to a frequency amplifier, dynamic recordings were taken (Fig. 3).

1. For in vivo recording, the patients were asked to swallow, drink water and chew biscuits three times. In each different test, the patients were allowed to rest for a sufficient period to relax their muscles (Figs. 4 and 5).

After completing all the recordings, calibrations were made by a static loading procedure outside the mouth.

2. In vitro recordings: Test dentures were lined with a layer of silicone base impression material having a thickness of $1 \mathrm{~mm}$ to simulate the mucosa on the ridges, and were placed on the self-curing acrylic jaw models (Fig. 6). Afterwards, calibration curves were evaluated by means of force exertion individually for each denture.

During the dynamic recording procedure, results were evaluated and marked 
on the calibration curves obtained and calculated in grams with the aid of an optical recorder (Table 1).

\section{Results}

For the evaluation of findings, average values, standard deviation and $t$ test were used (Table 2).

In the first group, the force of swallowing was measured on three different parts of the denture base with the aid of strain gauges (Table 3a, b, c).

The maximum force, which was $2820 \pm 540 \mathrm{~g}$, was recorded during swallowing, and the minimum force, which was $1900 \pm 320 \mathrm{~g}$, was recorded during water drinking through the strain gauge G1. Again, from the same location while swallowing masticated food, an average force of $2670 \pm 360 \mathrm{~g}$ was recorded.

Although there were some mathematical differences between the values, such differences were statistically insignificant (Table 3a). In the G2 strain gauge region, again the maximum force occurred, being $41 \pm 6 \mathrm{~g}$ during swallowing, while the minimum as $24 \pm 2 \mathrm{~g}$ during water drinking, and this was statistically significant $(\mathrm{P}<0.05)$. Again from the same strain gauge, it was found that the force occurring during swallowing was $36 \pm 6 \mathrm{~g}$, which was statistically insignificant (Table $3 \mathrm{~b}$ ). In the G3 strain gauge region, the maximum force that occurred was $165 \pm 11 \mathrm{~g}$ during the swallowing of masticated food, while the minimum force recorded was $18 \pm 2 \mathrm{~g}$ during water drinking, which was not statistically significant in comparison with the other two (Table 3c).

Again with the same strain gauge, $154 \pm 21 \mathrm{~g}$ of force was recorded during swallowing, which was mathematically and statistically significant in comparison with the force that occurred during water swallowing $(\mathrm{P}<0.001)$.

Table 2 Average differences and standard deviations of records which were obtained for the four different functions

\begin{tabular}{c|c|c|c|c}
\hline \hline $\begin{array}{c}\text { Strain } \\
\text { gauge }\end{array}$ & $\begin{array}{c}\text { Swallowing } \\
\bar{X} \pm \bar{S}_{x}(\mathrm{~g})\end{array}$ & $\begin{array}{c}\text { Drinking water } \\
\bar{X} \pm \bar{S}_{x}(\mathrm{~g})\end{array}$ & $\begin{array}{c}\text { Swallowing after chewing } \\
\bar{X} \pm \bar{S}_{x}(\mathrm{~g})\end{array}$ & $\begin{array}{c}\text { Mastication } \\
\bar{X} \pm \bar{S}_{x}(\mathrm{~g})\end{array}$ \\
\hline G1 & $2820 \pm 540$ & $1900 \pm 320$ & $2670 \pm 360$ & $4780 \pm 720$ \\
\hline G2 & $41 \pm 6$ & $24 \pm 2$ & $35 \pm 6$ & $4130 \pm 440$ \\
\hline G3 & $154 \pm 21$ & $18 \pm 2$ & $165 \pm 11$ & $4830 \pm 760$ \\
\hline
\end{tabular}

Table 3 The $t$ values of the results which were obtained using the strain gauges in four different functions

a)

b)

\begin{tabular}{l|c|c|c|}
\hline $\mathrm{G} 1$ & $\mathrm{~S}$ & $\mathrm{DW}$ & $\mathrm{CS}$ \\
\hline $\mathrm{DW}$ & 1.47 & & \\
\hline $\mathrm{CS}$ & 0.23 & -1.60 & \\
\hline $\mathrm{M}$ & $-2.18^{*}$ & $-3.65 * *$ & -2.62 \\
\hline$*(\mathrm{P}<0.05)$ \\
$* *(\mathrm{P}<0.001)$
\end{tabular}

\begin{tabular}{|c|c|c|c|}
\hline $\mathrm{G} 2$ & $\mathrm{~S}$ & $\mathrm{DW}$ & $\mathrm{CS}$ \\
\hline $\mathrm{DW}$ & $2.69 *$ & & \\
\hline $\mathrm{CS}$ & 0.71 & -1.74 & \\
\hline $\mathrm{M}$ & $-2.29 * *$ & $-9.33 * *$ & $-9.30 * *$ \\
\hline
\end{tabular}

c)

\begin{tabular}{|c|c|c|c|}
\hline $\mathrm{G} 3$ & $\mathrm{~S}$ & $\mathrm{DW}$ & $\mathrm{CS}$ \\
\hline $\mathrm{DW}$ & $6.44^{* *}$ & & \\
\hline $\mathrm{CS}$ & -0.46 & $-13.1^{* *}$ & \\
\hline $\mathrm{M}$ & $-6.11^{* *}$ & $-6.33^{* *}$ & $-6.14^{* *}$ \\
\hline
\end{tabular}


Table 4 The $t$ values of strain gauge results which were evaluated for different functions

a)

\begin{tabular}{|l|l|l|}
\hline $\mathrm{S}$ & $\mathrm{G} 1$ & $\mathrm{G} 2$ \\
\hline $\mathrm{G} 2$ & $5.1^{* *}$ & \\
\hline $\mathrm{G3}$ & $4.9^{* *}$ & $-5.2^{* *}$ \\
\hline \multirow{2*}{*}{$(\mathrm{P}<0.001)$}
\end{tabular}

b)

\begin{tabular}{c|c|c|}
\hline $\mathrm{DW}$ & $\mathrm{G} 1$ & $\mathrm{G} 2$ \\
\hline $\mathrm{G} 2$ & $5.9^{* *}$ & \\
\hline $\mathrm{G} 3$ & $5.9^{* *}$ & $2.12^{* *}$ \\
\hline & $\begin{array}{l}*(\mathrm{P}<0.005) \\
\text { **(P }<0.001)\end{array}$
\end{tabular}

c)

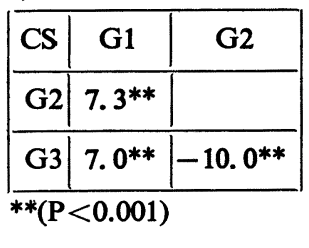

d)

\begin{tabular}{l|c|c|}
\hline $\mathrm{M}$ & $\mathrm{G} 1$ & $\mathrm{G} 2$ \\
\hline $\mathrm{G} 2$ & $0.18^{*}$ & \\
\hline $\mathrm{G} 3$ & $-0.007^{* *}$ & $-0.18^{* *}$ \\
\hline
\end{tabular}

S: Swallowing DW: Drinking water CS: Swallowing after chewing

M: Mastication

The difference in the forces that occurred between swallowing and masticating was statistically insignificant.

In the second group, again with the same strain gauge, difference in force transmittance between three different types of swallowing and mastication was examined.

In the $\mathrm{G} 1$ strain gauge region, $2820 \pm 540 \mathrm{~g}, 190 \pm 320 \mathrm{~g}$ and $2670 \pm 360 \mathrm{~g}$ forces were recorded during three different types of swallowing, which were statistically significant $(\mathrm{P}<0.001)$ (Table $4 \mathrm{a}, \mathrm{b}, \mathrm{c})$.

In the Group 2 strain gauge region, the maximum force was $41 \pm 6 \mathrm{~g}$ and in the Group 3 region $165 \pm 11 \mathrm{~g}$, which was again statistically significant $(\mathrm{P}<0.001)$ (Table $4 a, b, c)$.

In the third group, the forces that occurred during mastication in the G1, G2 and G3 regions were examined. The maximum chewing force was $4830 \pm 760 \mathrm{~g}$, which was again statistically significant $(\mathrm{P}<0.001)$ (Table $3 a, b, c$ and Table $4 d)$.

\section{Discussion}

In evaluating our findings, it was found that among different swallowing functions, the maximum force was exerted during voluntary saliva swallowing, rather than when crushing or drinking food. During swallowing of solids, a similar force was exerted, whereas during swallowing of liquids, a smaller force was applied.

CUTRIGHT et al. ${ }^{[2]}$ took recordings during mastication, drinking and swallowing, and found that the largest force applied during functional movements was at the moment of normal swallowing in an empty mouth. Also, in parallel with our study, they stated that the force exerted in daily swallowing functions was about $1750-2500 \mathrm{~g}$, and that this was much greater than other daily functional forces.

When we compared the forces occurring in three different locations on the maxillary denture, it was found that the G1 strain gauge recorded the maximum force. We can say that this was the result of occlusion and tongue pressure during swallowing. Therefore, swallowing force in the G1 region is due to occlusion of the teeth. This result seems to agree with that obtained by other groups of researchers who have also worked on the matter ${ }^{[6,7]}$.

Also in our study we determined the functional forces exerted during chewing in order to make a comparison with the forces occurring during swallowing.

When we compared the mastication forces in the G1, G2 and G3 regions, there was no significant difference. However, when we compared the differences between the three types of swallowing and mastication forces, functional force 
during mastication was always higher.

As some researchers have stated, we also found that swallowing forces were not as high as chewing forces, but that the number of swallowings and their duration may exert much more pressure on the denture-bearing tissues ${ }^{[8,10]}$.

Thus from our present study, we can conclude that the forces occurring during functional movements of the mouth will cause some deformation of the denture base, and that this will have an adverse effect on the underlying tissues of the denture.

\section{References}

[1] ÇALIKkocaoĞLu, S.: Tam Protezlerde Ölçü, Gençlik Basımevi, İstanbul, 1976

[2] Cutright, D.E., Brudvik, J.S., GAY, W. and Selting, W.J.: Tissue pressure under complete maxillary dentures, J. Prosthet. Dent., 35, 160-170, 1976

[3] LeDLeY, R.S.: New method of determining the functional forces applied to prosthetic appliances and their suppotring tissues, J. Prosthet. Dent., 5, 546-562, 1955

[4] Regli, C.P. and Gaskill, H.L.: Denture base deformation during function, J. Prosthet. Dent., 4, 548-554, 1954

[5] LAMBRECHT, J.R. and KYDD, W.L.: A functional stress analysis of the maxillary complete denture base, J. Prosthet. Dent., 12, 865-872, 1962

[6 EICHNER, Von K.: Aufschlüsse über den Kauvorgand durch elektronische Kaukraftmessungen, Dtsch. Zahnärztl. Z., 19, 415-425, 1964

[7] KöRBER, Von E.: Untersuchungen am Prothesenlager während des Kauens, Dtsch. ZahnMund-Kieferhk., 45, 100-111, 1965

[8] Ohashi, M., Woelfel, J.B., and Paffenbarger, C.C.: Pressure exerted on complete dentures during swallowing, J. Am. Dent. Ass., 73, 625-630, 1966

[9] SwOope, C.C. and KYDD, W.L.: The effect of cusp form and occlusal surface area on denture base deformation, J. Prosthet. Dent., 16, 34-43, 1966

[10] Watson, C.J. and ABdul WAHAB, M.D.: The development of an inexpensive pressure transducer for use at the denture base-mucosal surface interface, Brit. Dent. J., 156, 135-140, 1984

[11] Graber, T.M.: Orthodontics: Principles and Practice, Second Ed., Saunders Co., London, 1978

[12] Hickey, J.C. and ZARB, G.A.: Boucher's Prosthodontic Treatment for Edentulous Patients, Eighth Ed., The C.V. Mosby Co., St. Louis, 1980 